\title{
The Value of Life Design Counselling for an Adolescent who Stutters
}

\author{
Jacobus G. Maree \\ Yolene Hancke \\ University of Pretoria
}

Address correspondence to Professor Jacobus G. Maree, Faculty of Education, University of Pretoria, 0001, Pretoria, South Africa. E-mail: kobus.maree@up.ac.za

This study reports the results of a life design approach case study with an adolescent with stuttering. A variety of postmodern techniques were used to engage the adolescent in life design conversations about a preferred and meaningful future. Post-intervention, the individual seemed more capable of making a career choice with a sense of empowerment or personal agency. Life design counselling enabled the individual to engage in meaningful career exploration.

Keywords: counselling, identity, adolescent, stuttering, life design, career construction, adaptability, case study

Adolescents wanting to enter the South African labour market are faced with unique, context-specific challenges including fewer work opportunities, affirmative action and discrimination because of being intellectually, emotionally or physically challenged (Hancke, 2010). Counselling could assist adolescents learn about and explore the job market more effectively. Amundson (2005) maintains (a) that people use their decisions and actions to construct meaning and (b) that counselling is aimed at helping people express and judiciously re-examine their personal career constructions. Two concepts in particular that are related to career management theory: 'boundaryless' (Arthur \& Rousseau, 1996) and 'portfolio' (Hall, 1992, 1996). Whereas boundaryless signifies a "independence from, rather than dependence on, traditional organizational career arrangements" (Arthur \& Rousseau, 1996, p. 6), portfolio implies that individuals "contract their skills in a variety of contexts and self-employed arrangements" (Fenwick, 2004, p. 2).

\section{Stuttering}

According to Sue, Sue and Sue (2000), stuttering is an interruption in the flow of speech that is inappropriate for a given level of development. Stuttering is often associated with stress and can be seen as a condition that affects an individual's functioning in or interaction with a given system. The concept 'stuttering' is linked to terms such as 'language', 'culture', 'cultura identity' and 'diversity'. According to Louw (1996), language relates to a specific context. It is a form of human social behaviour that enables people to communicate with other people by producing meaningful utterances. This also includes the capacity to understand what others say.

According to Chope and Consoli (2007), language is a source of identity formation for people from all cultures. All people acquire a sense of identity by using language. Watson and Kuit (2007) argue that language is used to construct meaning during the process of life design when the focus shifts to the telling of a life story in an attempt to facilitate the design of a successful life. From the constructionist approach these narratives are seen as an individual's interpretation of meaning in his or her life. Adolescent and facilitator enter into a co-constructive relationship through dialogue. If an adolescent experiences a language disorder, his or her problematic use of language results in ineffective communication (Louw, 1996). From a constructionist point of view, narratives are seen as an individual's interpretation of the meaning and significance of his or her life.

The developmental tasks of an adolescent who stutters include the attainment of developmental-related attitudes, beliefs and behavioural patterns (Ackerman, 2005) as well as attitudes, beliefs and behavioural patterns that impact the challenge of stuttering - an impediment that can influence the stuttering adolescent's future and possible career. The assignments that have to be mastered by such adolescents are significantly more onerous than those of adolescents who do not stutter. Viewed from a systems theory perspective, an adolescent who stutters should be regarded as an individual system at a time of complex change. The complex context of an adolescent who stutters renders systems theory an appropriate means of viewing and investigating this system.

\section{Life Design Counselling}

Savickas (2010, p. 15) asserts that career construction theory offers people a way of considering ways in which to (a) construct careers and (b) design successful lives. By emphasising the notions of life portraits, narratability and biographicity, this theory provides an eloquent and viable explanation for the way in which people experience and construct their lives and their worlds. Career construction counselling maintains that by asking people to compose life portraits and subsequently narrate their biographies to an audience that listens to and validates these life portraits, the process of self-making and learning to develop and grow personally and professionally is set in motion. Watson and Kuit (2007) state that the overall aim of life design counselling is to provide an alternative approach to career facilitation. Life design counselling also implies a co-constructive process during which life design either commences or is continued. This approach empowers individuals to function more successfully with their complex, subjective and interdependent contexts. The focus is thus on a dynamic process rather than on a set of inflexible rules. Hartung (2007) states that adolescents' self-defining stories about life structure (role importance), ca- 
reer adaptability strategies (participation, control, curiosity and confidence), life themes (motivation and strivings) as well as personality style are taken as the point of departure for the design of a successful career story. Metaphoric language in dramatic form is used to interpret adolescents' stories clearly and coherently. Dialogue plays an integral role in life design counselling (Fritz \& Beekman, 2007) and provides the key to adolescents' participation in the life design counselling process. The facilitator should take adolescents' level of development and language ability into account during the life design counselling process. Chope and Consoli (2007) believe that the narrative facilitator should, for instance, ascertain how many languages the adolescents have mastered, how their accent influences their perceptions of themselves when they attempt to find work and how people react to the way in they speak. A challenge such as stuttering (which is essentially a language-related issue) will therefore inevitably influence the life design counselling process. The matters delineated above should be considered during life design counselling.

\section{Career Adaptability Concepts}

This dimension of career construction theory focuses on the developmental tasks and role transitions in the areas of career concern, career control, career curiosity and career confidence.

Career concern. The first and most important dimension of career adaptability is people's concern about their own career future (Savickas, 2005). Career concern refers to the belief that people have a future that is worth preparing for and that this preparation will enhance their future.

Career control. A feeling of optimism regarding the future leads to concern about who owns a person's future. Career control indicates that people feel and believe that they themselves are responsible for the construction of their careers.

Career curiosity. Career curiosity refers to inquisitiveness to learn more about types of occupations the individual may be interested in as well as the opportunities that accompany such occupations (Savickas, 2005). Career curiosity, according to Hartung (2007), refers to productive career investigation and a realistic approach to the future.

Career confidence. Career confidence comprises two closely related components: an increase in problem-solving capabilities and the belief that people can act effectively.

An adolescent who stutters may experience problems regarding his or her participation in a predominantly narrative approach to life design counselling. Nonetheless, she or he may benefit from a narrative approach to life design counselling because meaning can be created within a stutterer's unique language participation context.

\section{Systems Theory as a Means of Explaining the Idiosyncratic Situation of an Adolescent who Stutters}

Adolescents find themselves in a life world that comprises different systems. Donald, Lazarus and Lolwana (2002) maintain that educational psychologists should be aware of the interplay between systems and adjacent systems and/or subsystems as such interplay influences individuals directly or indirectly.

\section{Goals of the Study}

We investigated the value of a life design counselling process for an adolescent who stutters and who expressed a need for career counselling. We facilitated life design counselling through co-constructive dialogue with the adolescent. In this article, we investigated the value of a life design counselling process for an adolescent who stutters. We endeavoured to facilitate life design counselling through co-constructive dialogue with the adolescent. More particularly, we investigated the specific meaning an adolescent who stutters attaches to the dimensions of career adaptability, making meaning of life and becoming more whole as a person.

\section{Method}

\section{Participant and Context}

The participant $\left(\mathrm{John}^{1}\right)$ was a purposefully selected male, white, Afrikaans speaking learner in Grade 9 who stuttered. Selection criteria called for an adolescent who stuttered and who sought career counselling.

\section{Procedure: Multi-method Data-Gathering Plan}

The investigation was based on an interpretivist paradigm involving understanding and interpreting meanings as revealed during interactions. The research design was qualitative in nature (Creswell, 2007; Durrheim, 1999) and comprised a case study (McMillan \& Schumacher, 2001; Whitley, 2002).

\section{Data Gathering}

The adolescent took the Myers-Briggs Type Inventory (MBTI) (Briggs \& Briggs Myers, 1994) and the Career Adapt-Abilities Inventory (Savickas, 2009c). As the latter instrument is in the process of being standardised globally, the results obtained from its administration were interpreted qualitatively only. The tests were scored by an independent person who was 'blind' to the study. In addition, qualitative data were gathered using in-depth (one-on-one, semi-structured) interviews and oral discussions with John and observing him. The following techniques were employed to facilitate data collection: the Collage, the Career Interest Profile (Maree, 2010), the success and failure experiences, life story and life line techniques (Cochran, 1997; 2007), the career-story interview (Hartung, 2010; Savickas, 2009a, b) and informal conversation.

\section{Intervention}

The intervention incorporated postmodern career facilitation techniques (Maree \& Molepo, 2007) to enhance John's involvement in his life design process and to facilitate co-constructive conversation. A life design counselling process was developed and implemented during six sessions (Hancke, 2010). Qualitative data sources were (i) observation (Cohen, Manion \& Morrisson, 2000; Terre Blanche \& Kelly, 1999) by the researchers, which was documented in field notes and a research diary (McMillan \& Schumacher, 1997), and (ii) informal conversational data during the interaction between the participant and the researchers, which were recorded and transcribed.

The intervention model for life designing is based on stories and activities rather than just test scores and profile interpretations. Briefly summarised, the strategy has six general steps that are informed by and tailored to the idiosyncratic reality represented by the unique experience of each person. First, the problem needs to be defined by both the counsellor and the client, and client's hopes regarding what he or she hopes to achieve during the counselling have to be established. In the next step (once the problem and context of the problem have been identified), the client is encouraged to explore his or her 
existing system of subjective identity shapes. In the third step in the life design intervention process, the counsellor and the client focus on the widening of perspectives of the client. The story has then to be revised, after which the fourth step occurs: the client places the existing problem within his or her revised story. In the penultimate step, the client is encouraged to identify activities he or she can carry out to actualise his or her new identity. The last (sixth) step comprises short-term and long-term follow-up interventions (Savickas et al., 2009; Duarte, 2009; 2010).

\section{Data Analysis}

A deductive approach was followed for the purpose of the data analysis. The data were evaluated and categorised according to predetermined themes found in the literature (Creswell, 2007; McMillan \& Schumacher, 2001).

For the purpose of data analysis, the documented data were organised, and themes, subthemes and categories identified. The core theme of the study is the adaptability needs of an adolescent who stutters and, more specifically, the handling of these needs from a life design perspective. A template style of data analysis was used to apply themes to the data (McMillan \& Schumacher, 2001). Predetermined themes were identified from the literature (Savickas, 1995; 2003; 2005; Hartung, 2007; Watson \& Stead, 2006). The four dimensions of adaptability, namely career concern, career control, career curiosity and career confidence, were used as the predetermined themes. These themes relate to the central theme of the study and were used to elaborate on the central theme. In order to realise the full potential of the co-constructive nature of interpretivist research, our intention was not to make interpretations but to present a nuanced understanding of the participant's life design process as it emerged during the study. Verbatim responses from the participant's sessions will be given to illustrate the emergence of significant themes. The data were then evaluated and categorised (Creswell, 2007), and, finally, the identified themes were compared with existing knowledge (literature) on life design.

\section{Literature Control}

Identified themes will normally crystallise in a combination of three ways. Crystallised themes will either confirm findings in the literature, refute those findings or, by way of new insights, make a contribution to the literature. Marshall and Rossman (1995) claim that an important function of literature control is the identification of shortcomings in the available literature so that the researcher can indicate the extent to which the study addresses these shortcomings. According to Wisker (2001), researchers should familiarise themselves with what has been written by others. Literature control enables researchers to stay abreast of developments in a particular field or subject.

\section{Ethical Issues}

Measures to ensure the research participant's well-being were implemented throughout the study. Informed consent was obtained from him, and confidentiality was guaranteed and maintained. The researchers gave feedback to the participant during all the phases of the study. The research findings were released in an acceptable and responsible manner (Whitley, 2002).

\section{Results}

The seven main themes, which emerged from a qualitative analysis of the data, evidently played a significant role in the life design process of the participant, namely concern, control, curiosity, confidence, coping mechanisms, interpersonal relationships, and a dynamic and painful past. These main themes are discussed together with the meaningful subthemes, after which the link between the themes and the stages of the life design process will be elucidated.

A summary of the main themes that were confirmed and the subthemes that emerged during the life design counselling process, as well as the relevant sources of information, is given below in Table 1. A summary of the main themes and the subthemes identified in an inductive manner appear in Table 2.

\section{Theme 1: Career Concern}

According to Hartung (2007), career concern comprises an adolescent's orientation towards the future and his or her optimism regarding the future. John confirms this view: I am looking ahead to my future and I believe that I can be successful. Savickas (2005) shows that many diligent adolescents use thoroughness as a skill to ensure career concern. John puts it this way: Then I will just have to find a way to get to the top and So I will just have to adapt a little more and I will have to look at other options if what I want to do doesn't work out. Savickas (2005) argues that lack of concern about a career manifests as a problem under the heading career concern. John gives evidence of lack of concern by saying, I am not thinking about my future as yet. Even though I realise that my decisions will influence my future I am not considering its impact on my future right now. Savickas (2005) believes that adolescents may develop a dependency on their counsellors as a result of lack of career concern. This evidenced by the following statement by John: I want my counsellor to tell me what to do.

\section{Theme 2: Career Control}

Duarte (2010) believes that the process of life design counselling encourages adolescents to accept ownership of their future. John confirms this by saying, I realise that I know myself better than anyone else and I would rather make a choice that opens a number of possibilities for me than making a wrong decision at such a young age and It will be difficult to turn back at a later stage.

\section{Theme 3: Career Curiosity}

Hartung (2007) believes that career concern includes entry into productive career investigation as well as a realistic approach to the future. John indicates that he intends to do job analysis by way of work shadowing ... as soon as possible. $\mathrm{He}$ also confirms that he is realistic about the possibility of starting his own business but that he wishes to start in a modest way: I want to make a small beginning myself and systematically expand and grow. I want to practise engineering to get people to come to me and fix their broken stuff [after which] I will take it further.

\section{Theme 4: Career self-confidence}

According to Hartung (2007), self-confidence is indicative of an adolescent's problem-solving skills as well as his or her self-sufficiency. John uses problem-solving skills to enable him to participate in the life design counselling process by writing down certain words that he knows he will struggle to articulate, thereby enabling himself to participate meaningfully in the pro- 
Table 1

Identified Themes Based on the Literature

Theme identified

Source of data

\section{Main theme: Concern}

Concern about career future

Positive regard for the future

Anticipation of events

Optimism/Hope

Planning

\section{Main theme: Control}

Independence

Perseverance

Interpersonal autonomy

Intrapersonal will power

Strong value system

Ownership of future

Main theme: Curiosity

Self-knowledge

Openness towards new experiences

\section{Main theme: Confidence}

Problem-solving strategies

Self-acceptance

Self-value

Expectation of success
Collage, Motto, Career Interest Profile (Maree, 2010), Three anecdotes, Genogram, Career Adapt-Abilities Inventory (Savickas, 2009c)

Motto, Life line, Career Adapt-Abilities Inventory (Savickas, 2009c)

MBTI (Briggs \& Myers Briggs, 1994), Life line Career Adapt-Abilities Inventory (Savickas, 2009c), Genogram

Collage, Motto, Three anecdotes, Life line

Motto, Career Interest Profile (Maree, 2010), Collage, Genogram, Career

Adapt-Abilities Inventory (Savickas, 2009c)

Three anecdotes

Career Adapt-Abilities Inventory (Savickas, 2009c)

Motto, Career Adapt-Abilities Inventory (Savickas, 2009c), Three anecdotes, Life line, Genogram

Life line, Genogram, Career Interest Profile (Maree, 2010)

Collage, Genogram, Career Adapt-Abilities Inventory (Savickas, 2009c), Career Interest Profile (Maree, 2010)

Motto, Life line, Genogram

Collage, Career Interest Profile (Maree, 2010), Career Adapt-Abilities Inventory (Savickas, 2009c), Three anecdotes, Life line, Genogram

MBTI (Briggs \& Myers Briggs, 1994), Three anecdotes, Genogram, Career Interest Profile (Maree, 2010)

Career Adapt-Abilities Inventory (Savickas, 2009c), Career Interest Profile (Maree, 2010), Collage, Life line, Three anecdotes

Life line, Collage, Genogram, Career Interest Profile (Maree, 2010)

Life line, Career Adapt-Abilities Inventory (Savickas, 2009c), Three anecdotes, Genogram, Career Interest Profile (Maree, 2010)

Career Interest Profile (Maree, 2010), Career Adapt-Abilities Inventory (Savickas, 2009c), Three anecdotes cess. John also uses self-sufficiency to participate in the process: When we speak softly I stutter less. Furthermore, he remarks, I find it easier to speak in front of my friends ... I get nervous when I have to speak to strangers. He applies this self-knowledge to enable himself to consider opening his own business: Once I get to know them and they get to know me I will be able to speak comfortably when talking with my employees.

\section{Theme 5: Coping Mechanisms}

Pollard (2008) found that South African adolescents' future perspective and planning in general are limited to what they intend to do during the next two years of their lives. She (Pollard, 2008) suggests that there is a general inability to consider alternative choices and that avoidance behaviour and passivity re garding career choice making are common. John displays avoidance behaviour when stating, I do not think about my future very often. According to Schreuder and Coetzee (2006), the psychological, physical and social well-being of an individual is affected by the manner in which she or he deals with stress and additional demands. Different individuals display different types of coping mechanisms depending on the nature of specific stressors (Kohn, O'Brien-Wood, Pickering \& Decicco, 2003). Most adolescents use problem-focused strategies when they perceive stressors to be controllable but emotion-focused behaviour when stressors are perceived to be beyond their control. John used problem-focused behaviour during the life design counselling process.

\section{Theme 6: Interpersonal Relationship Dimensions}

Chope and Consoli (2007) argue that the identity of individuals is created in relation to other persons, institutions, communities and cultures. John sets great store by the support of family and friends: Look, my parents mean the world to me and my friends are important to me and If I play rugby away from home, it will be impossible for my parents to come and watch me. He displays a need for recognition in the school context by stating that he plays first team rugby and that he enjoys the support of spectators in particular.

\section{Theme 7: (Dealing with the) Painful Past}

Strauser, Lustig and Ciftci (2008) found that individuals experience less anxiety regarding the future when they have a 
Table 2

Additional Themes Identified

Themes identified

Source of Data

Main theme: Coping mechanisms

Denial/Avoidance behaviour Three anecdotes, Career Adapt-Abilities Inventory (Savickas, 2009c)

Main theme: Interpersonal relationship dynamic

Need for recognition

Need for acceptance

Need for support

Need to belong

Isolation/Loneliness

Support

Good people knowledge

Main theme: Painful past

Failure experience
Collage, Three anecdotes, Life line

Life line, Three anecdotes, Career Interest Profile (Maree, 2010)

Collage

Life line, Three anecdotes

Collage, Career Adapt-Abilities Inventory (Savickas, 2009c)

Life line, Career Adapt-Abilities Inventory (Savickas, 2009c), Career Interest Profile

(Maree, 2010)

Career Adapt-Abilities Inventory (Savickas, 2009c), Career Interest Profile (Maree, 2010)

MBTI (Briggs \& Myers Briggs, 1994), Career Interest Profile (Maree, 2010), Three anecdotes, Life line, Genogram clear goal and a sense of direction in life; when they have decided on a set of clear outcomes for their lives and believe that life is meaningful. Despite having suffered setbacks in the past, John sees these stumbling blocks is as a great opportunity for growth. There isn't such a thing as failure, only earlier attempts ts at success. John declares himself willing to learn from his failures in the past, and he feels positive about the future because he has a clear goal and sense of direction in life: So I showed my teachers I am here for a reason and I believe I have a bright future. Even though John finds it difficult to speak or even write in front of strangers, he has learnt to use coping skills to deal with experience of failure. He will, for instance, pull his cheeks tightly or use an 'easier' word when he stutters.

\section{Stages of the Life Design Process}

The themes identified during the study are discussed according to the stages of the life design counselling process. By discussing the data according to stages rather than individual sessions, we acknowledge the interconnectedness of the themes while addressing the central theme, namely the handling of adaptability needs from a life design perspective. The stages according to which the themes are discussed are (a) constructing a working alliance, (b) mapping and exploring a system of subjective identity forms, (c) opening perspectives, and discovering, rewriting, reorganising and revising life stories, (d) placing the problem in a new story and perspective, (e) specifying and selecting activities that investigate issues surrounding identity and, lastly, (f) conducting a follow-up session (Savickas, et al., 2009).

Construction of a 'working alliance'. We had to gain a clear understanding of John's (the participant) unique context and challenges. He wanted to know, What careers are there for me? He soon realised that I am the expert on my own life and that he had to take ownership of his career choice. He seemed to struggle in the school context, and in this regard said, $A$ lot of times when I have to talk or read out loud, I begin to stutter. His family life is a context where he sees his parents as important role players in providing support. He clarified his roles as a leader in school and a sports achiever.

Mapping and exploring the adolescent's system of subjective identity forms. The system of subjective identities is explored in order to analyse the identity image in different contexts (Guichard, 2009). John's previous experiences show that he experienced isolation and felt lonely in his school context. He said, It feels that everyone is against me. His current identity image reveals his ability to change his failures into successes: To see what I have achieved in primary school and in sport, it helped me to realise that I could do it - it helped build my self-confidence. He has positive future aspirations when he says I believe that I have a bright future.

Opening and extending the adolescent's perspectives. During this stage, John's life story is rewritten using the information gathered in Stages 1 and 2. Strengths such as self-knowledge were identified when he said I am not really a person who sits still. He showed anticipation for future events by saying If I want to be an electrical engineer I have to consider going to a technical school. Problem-solving abilities were also identified as a strength when he stated, I will use another word to substitute the problematic word which causes me to stutter. His weaknesses were also noted, for example, when he said, I don't often think about my future, I take it as it comes. Isolation and feelings of loneliness were also identified as weaknesses.

Placing the problem into a newly retold story. John's expectations were reinterpreted: I realised that if I want to do something, I can. He thus decided to take an active role in the career decision-making process.

Specification and selection of activities that examine issues of identity to establish a concrete plan of action with defined tasks. Together with John (the participant), we decided on specific activities to actualise the co-constructed life design. He had to continue his life line, write his life chapters and do work analysis including work shadowing. 
Follow-up. In the follow-up interview, John stated that he had started with work analysis. He said that he found life design counselling to be helpful as it had given him a sense of planning ahead for his future.

\section{Discussion}

Life design counselling is described by researchers (Duarte, 2010; Maree, 2010; Savickas et al., 2009; Zunker, 1998) as a potentially useful strategy to augment the design of an individual's life to help him or her face repeated transitions as and when they happen. This description is largely supported by this case study, which underscores the value of a life design counselling process for an adolescent who stutters. The study focused on adaptability as an element of this particular adolescent's life design; more specifically, on the way that the four core dimensions of adaptability - career concern, career control, career curiosity and career confidence - manifested in his life.

The study uncovered the distinctive nature of the participant's context, the inter-reliant relationship between the participant and the different systems with which his life was intertwined, how he found meaning from the process as well as the objective but especially the subjective significance he attached to the experience and how he was attempting to deal with the challenges he was experiencing at present. After a two-month period, the participant gave evidence of an enhanced level of career adaptability in terms of concern, control, curiosity and self-confidence. He showed promising signs of a willingness to accept responsibility for his future as indicated by his concluding comment during the last session: I intend to give all I have and try my best. Given the support structures I have and what I have learned, things will fall into place as time moves on.

\section{Limitations}

Because only one case study was investigated, the scope of the study was limited. Although specific steps were taken to enhance the trustworthiness and credibility of the study, the subjective interpretation of the researchers could be viewed as a limitation.

\section{Conclusion}

The conversation transcriptions reveal the usefulness of a life design counselling process in enhancing the design of the participant's life so that can adapt readily and flexibly as and when needs change and new challenges arise. Our discourses seem to have assisted John in achieving an enhanced awareness of his inherent strengths and even an appreciation of his weaknesses as potential areas for growth and development. Towards the end of our conversations, John gave every indication of sensitive self-insight about his past and present experiences and an awareness of the need to constantly reconsider 'invalid' perceptions.

The qualitative, descriptive and explorative nature of the study contributed to the rich and dense description of an adolescent who stutters. Life design counselling seemingly offers an encouraging strategy for adolescents who stutter. The postmodern techniques implemented in the study also improved John's (the adolescent in question) participation in the life design process.

\section{Endnotes}

${ }^{1} \mathrm{~A}$ pseudonym is used in the case study.

\section{References}

Ackerman, C. (2005). Promoting development during adolescence. In P. Engelbrecht \& L. Green (Eds.), Promoting learner development (pp. 101-120). Pretoria, South Africa: Van Schaik.

Amundson, N. (2005). The potential impact of global changes in work for career theory and practice. International Journal for Educational and Vocational Guidance, 5, 91-99.

Arthur, M. B., \& Rousseau, D. M. (1996). The boundaryless career: A new employment principle for a new organizational era. New York, NY: Oxford University.

Briggs, K. C.. \& Briggs Myers, I. (1994). Myers-Briggs Type Indicator. Palo Alto, CA: Consulting Psychologists Press.

Chope, R. C., \& Consoli, A. J. (2007). A storied approach to multicultural career counselling. In K. Maree (Ed.), Shaping the story: A guide to facilitating narrative counselling (pp. 87-100). Pretoria, South Africa: Van Schaik.

Cochran, L. (1997). Career counselling: A narrative approach. Thousand Oaks, CA: Sage.

Cochran, L. (2007). The promise of narrative career counselling. In K. Maree (Ed.), Shaping the story: A guide to facilitating narrative counseling (pp. 7-19). Pretoria, South Africa: Van Schaik.

Cohen, L., Manion, L., \& Morrison, K. (2000). Research methods in education (5th ed.). London, England: Routledge.

Creswell, J. W. (2007). Qualitative inquiry and research design: Choosing among five approaches (2nd ed.). London, England: Sage.

Donald, D., Lazarus, S., \& Lolwana, P. (2002). Educational psychology in social context. Cape Town: Oxford University Press Southern Africa.

Duarte, M. E. (2009). The psychology of life construction. Journal of Vocational Behaviour, 75(3), 259-266.

Duarte, M. E. (2010, July). Restructuring career counselling: objectives and instruments. In R. Van Esbroeck (Convenor) Life Design Symposium. Symposium presented at the 27th International Congress of Applied Psychology, Melbourne, Australia.

Durrheim, K. (1999). Research design. In M. Terre Blanche \& K. Durrheim (Eds.), Research in practice: Applied methods for the social sciences (pp. 29-53). Cape Town, South Africa: University of Cape Town Press.

Fenwick, T. J. (2004). Learning in portfolio work: Anchored innovation and mobile identities Studies in Continuing Education, 26 (2), 229-241.

Fritz, E., \& Beekman, L. (2007). Engaging adolescents actively in telling stories and actualising dreams. In K. Maree (Ed.), Shaping the story: A guide to facilitating narrative counseling (pp.163-175). Pretoria, South Africa: Van Schaik.

Guichard, J. (2009). Self-constructing. Journal of Vocational Behavior, 78(3), 251-258.

Hall, D. T. (1992). The strategic analysis of intangible resources. Strategic Management Journal, 13, 135-144.

Hall, D. T. (1996). The Career is dead: Long lives the career. San Francisco, CA: Jossey-Bass. 
Hancke, Y. (2010). The value of life design counselling for an adolescent who stutters (Unpublished master's dissertation). University of Pretoria, Pretoria, South Africa.

Hartung, P. J. (2007). Career construction: Principles and practice. In K. Maree (Ed.), Shaping the story: A guide to facilitating narrative counseling (pp. 103-120). Pretoria, South Africa: Van Schaik.

Hartung, P. J. (2010). Identifying life-career themes with the career-story questionnaire. In K. Maree (Ed.), Career counselling: methods that work (pp. 161-166). Cape Town, South Africa: Juta Academic.

Kohn, P. M., O’Brien-Wood, C., Pickering, D. I., \& Decicco, T. L. (2003). The personal functioning inventory: A reliable and valid measure of adaptiveness in coping. Canadian Journal of Behavioural Science, 35(2), 111-123.

Louw, D. A. (1996). Human development. Kaapstad, South Africa: Kagiso Tertiary.

Maree, J. G. (2010). Career Interest Profile (3rd ed.). Johannesburg, South Africa: van Rooyen.

Maree, J. G., \& Molepo, J. M. (2007). Facilitating postmodern career counselling in the Limpopo Province of South Africa: A rocky ride to hope. Australian Journal of Career Counselling, 16(3), 62-70.

Marshall, C., \& Rossman, G. B. (1995). Designing qualitative research (2nd ed.). Thousand Oaks, CA: Sage.

McMillan, J. H., \& Schumacher, S. (1997). Research in education. A conceptual introduction (4th ed.). New York, NY: Addison Wesley Longman

McMillan, J. H., \& Schumacher, S. (2001). Research in education. A conceptual introduction (5th ed.). New York, NY: Addison Wesley Longman.

Pollard, Z. (2008). The impact of life design counselling on an Afrikaans speaking adolescent (Unpublished master's dissertation). University of Pretoria, Pretoria, South Africa.

Savickas, M. L. (1995). Constructivist counselling for career indecision. Career Development Quarterly, 43(4), 363-373.

Savickas, M. L. (2003). Towards a taxonomy of human strengths: Career counselling's contribution to positive psychology. In W. B. Walsh (Ed.), Counseling psychology and optimal human functioning (pp. 229-249). London, England: Routledge.

Savickas, M. L. (2005). The theory and practice of career construction. In S. Brown \& R. Lent (Eds.), Career development and counseling: Putting theory and research to work (pp. 42-70). New York, NY: John Wiley.

Savickas, M. L. (2009a, April). Utilising early anecdotes in counselling in the 21st century. Keynote presentation, SA Society for Clinical Hypnosis. Pretoria, South Africa.

Savickas, M. L. (2009b, April). The essentials of life design counselling. Invited public lecture, University of Pretoria, Pretoria.

Savickas, M. L. (2009c). Career Adapt-Abilities Inventory. Unpublished working document, University of Pretoria, Pretoria, South Africa.

Savickas, M. L. (2010). Career studies as self-making and life designing. Career Research and Development, 23, 15-18.

Savickas, M. L., Nota, L., Rossier, J., Dauwalder, J.-P., Duarte, M. E., Guichard, J., . . Van Vianen, A. E. M. (2009). Life designing: A paradigm for career construction in the 21th century. Journal of Vocational Behavior, 75, 239-250.
Schreuder, A. M. G., \& Coetzee, M. (2006) (Eds.). Careers: An organisational perspective (3rd ed.). Landsdowne, South Africa: Juta.

Strauser, D. R., Lustig, D. C., \& Ciftci, A. (2008). Psychological well-being: Its relation to work personality, vocational identity, and career thoughts. The Journal of Psychology, 142(1), 21-35.

Sue, D., Sue, D. W., \& Sue, S. (2000). Understanding abnormal behaviour (6th ed.). Boston, MA: Houghton Mifflin.

Terre Blanche, M., \& Kelly, K. (1999). Interpretive methods. In M. Terre Blanche \& K. Durrheim (Eds.), Research in practice: Applied methods for the social sciences (pp. 123-146). Cape Town, South Africa: University of Cape Town Press.

Watson, M., \& Kuit, W. (2007). Postmodern career counselling and beyond. In K. Maree (Ed.), Shaping the story: A guide to facilitating narrative counseling (73-86). Pretoria, South Africa: Van Schaik.

Watson, M. B., \& Stead, G. B. (2006). The career development theory of Donald Super. In G. B. Stead \& M. B. Watson (Eds.), Career psychology in the South African context (2nd ed., pp. 52-64). Pretoria, South Africa: Van Schaik.

Whitley, B. E. (2002). Principles of research in behavioural science (2nd ed.). New York. NY: McGraw-Hill.

Wisker, G. (2001). The postgraduate research handbook: Succeed with your MA, MPhil, EdD and PhD. New York, NY: Palgrave.

Zunker, V. G. (1998). Career counselling: Applied concepts of life planning (5th ed.). Pacific Grove, CA: Brooks/Cole. 
